\title{
MHC structure and function - antigen presentation. Part 2
}

\author{
Estrutura do MHC e função - apresentação de antígenos. Parte 2
}

\author{
Anna Carla Goldberg ${ }^{1}$, Luiz Vicente Rizzo ${ }^{1}$
}

\begin{abstract}
The second part of this review deals with the molecules and processes involved in the processing and presentation of the antigenic fragments to the T-cell receptor. Though the nature of the antigens presented varies, the most significant class of antigens is proteins, processed within the cell to be then recognized in the form of peptides, a mechanism that confers an extraordinary degree of precision to this mode of immune response. The efficiency and accuracy of this system is also the result of the myriad of mechanisms involved in the processing of proteins and production of peptides, in addition to the capture and recycling of alternative sources aiming to generate further diversity in the presentation to T-cells.
\end{abstract}

Keywords: Major histocompatibility complex; Antigen presentation; HLA genes; Immune response

\section{RESUMO}

A segunda parte desta revisão trata das moléculas e processos envolvidos no processamento e apresentação dos fragmentos antigênicos ao receptor de célula-T. Apesar de variar a natureza do antígeno apresentado, a classe mais significativa é a das proteínas, as quais são processadas dentro da célula para enfim serem reconhecidas na forma de peptídeos, o que confere um grau extraordinário de precisão a essa forma de resposta imune. A eficiência e a precisão desse sistema se devem também à miríade de mecanismos envolvidos no processamento de proteínas e produção de peptídeos, além da captura e reciclagem de fontes alternativas de antígenos com 0 objetivo de gerar ainda maior diversidade na apresentação à célula-T.

Descritores: Complexo principal de histocompatibilidade; Apresentação do antígeno; Genes HLA; Resposta imune

\section{INTRODUCTION}

A central role for $\mathrm{MHC}$ in the immune response to protein antigens was suggested in the 1970 when experimental evidence showed that $\mathrm{T}$ lymphocytes recognize portions of antigens (peptides) only when bound non-covalently to products of the HLA genes. Crystallographic analysis of the HLAI molecule carried out in $1987^{(1)}$ disclosed how these peptides nest in the external part of the molecule, that is, in the peptidebinding groove.

\section{PART 2 - PEPTIDE GENERATION: PROCESSING, MECHANISMS OF DIVERSITY, AND ALTERNATIVE SOURCES FOR PRESENTATION}

Broadly, proteins are degraded inside cells, and peptides derived through this processing are coupled to HLA molecules and transported to the cell surface. HLAI and HLAII molecules transport peptides produced in different cellular compartments (proteasomes and endosomes, respectively), in which different proteolysis strategies employed generate the variety of peptides needed for an efficient presentation and recognition by $\mathrm{T}$ cell receptors. HLA plus peptide on one side bound to T-cell receptor on the other forms the trimolecular complex, which initiates and confers the necessary specificity to the effector immune response. ${ }^{(2)}$

\section{Peptide presentation via HLAI (2)}

The profile of peptides eluted from HLAI confirms the same molecule can present diversified sequences (approximately 10,000 distinct peptides per cell). Furthermore, the array of peptides presented by each HLA molecule varies according to the binding motif displayed by the respective grooves. ${ }^{(3,4)}$ The bewildering variety of peptides is mainly produced in the cytosol, within the proteasomes, multi-component complex

\footnotetext{
Hospital Israelita Albert Einstein, São Paulo, SP, Brazil.

Corresponding author: Anna Carla Goldberg - Avenida Albert Einstein, 627/701, 2ss floor, building A - Morumbi - Zip code: 05651-900 - São Paulo, SP, Brazil - Phone: (55 11) 2151-1233 E-mail: goldberg@einstein.br
}

Received on: Mar 27, 2014 - Accepted on: June 27, 2014

DOI: 10.1590/\$1679-45082015RB3123 
structures capable of enzymatic proteolysis, and are therefore of endogenous origin. ${ }^{(2)}$ Peptide diversity is further increased by proteasome component substitution during the immune response that leads to production of novel peptide fragments. ${ }^{(5)}$

Proteins involved in the cellular metabolism are synthesized in the endoplasmic reticulum, and when unnecessary or defective (called DRiPs, for Defective Ribosomal Proteins) that is, truncated or altered due to misfolding or erroneous translation ${ }^{(6)}$ are coupled to ubiquitin units. ${ }^{(7-9)}$ The ubiquitin tail transfers the tagged proteins to proteasomes for processing inside the catalytic center to 9 amino acid-long fragments. Other components of the proteasome complex carry out binding and unfolding of ubiquitin-tagged proteins in preparation for their fragmentation. ${ }^{(10)}$ This major protein degradation pathway has been shown to be a fundamental and universal cell function, and its discoverers, A. Ciechanover, A. Hershko, and I. Rose, were awarded the 2004 Chemistry Nobel Prize.

Peptides surviving the proteasomal processing are translocated into the endoplasmic reticulum by the TAP (for Transporter associated with Antigen Processing) heterodimer. ${ }^{(11)}$ The assembly of a HLAI molecule, its folding, and coupling of the peptide are complex processes which occur only with help of accessory proteins acting as chaperones. ${ }^{(11)}$ The list includes calnexin that confers stability and ERp57 (a disulfide isomerase) that helps to bind beta-2 microglobulin. Calreticulin then replaces calnexin and together with ERp57 and tapasin will form a peptide-loading complex (PLC) in charge of loading and favoring the correct insertion of peptides unto the nascent HLAI molecule. ${ }^{(12,13)}$ Tapasin also serves as the bridge between the PLC and peptide-carrying TAP. ${ }^{(13)}$ Finally, endoplasmic reticulum-associated amino peptidases (ERAP1 and ERAP2) carry out the fine tuning trimming peptides to the 8 to 10 amino acid size ideal for coupling to HLAI. ${ }^{(14)}$ Finally, the stable trimmer made up of the $\alpha$ heavy chain, $\beta 2-$ microglobulin, and peptide can be transported through the Golgi for glycosylation and arrival on the cell surface. This is the principal route for class I antigen presentation, and when devoid of peptides, HLAI exhibits a very short half-life and is rapidly degraded. In other words, empty HLA molecules are the exception.

This route of antigen processing, called cytosolic or endogenous, is excellently suited for viral peptide presentation when the cell is infected, as viruses employ the cellular machinery to produce their own proteins and new virus particles. However, studies have shown that their presentation is even more efficient than that of other peptides (1.5 hour instead of 8 hours as usual). This rapid degradation is made possible because viral proteins are seen as DRiPs by the cell. ${ }^{(2,15)}$ The cytotoxic response (via CD8 $+\mathrm{T}$ lymphocytes) against viruses is an essential feature of defense by the infected organism, and is frequently targeted by the invading pathogen with immune evasion strategies. Examples are cytomegalovirus, herpes simplex virus, and human immunodeficiency virus, which synthesize proteins capable of interrupting the flow of peptides, blocking TAP and even synthesis of class I molecules. ${ }^{(16)}$

In addition to the processing described above, several others are operating, including some recently identified, which add to the variety of peptides generated and presented. A list of these extra features follows:

1. different speeds in transport of HLAI molecules to the cell surface, where HLA-B exhibits the best efficiency; ${ }^{(17)}$

2. presentation by HLA-E (non-classical) of peptides derived from classical HLAI leader sequences for recognition by $\mathrm{CD} 94 / \mathrm{NKG} 2 \mathrm{~A}$ receptors on natural killer (NK) cells; ${ }^{(18)}$

3. presentation by HLA-G (non-classical) at the maternal-fetal interface, in which classical HLAI expression is very low, for recognition by KIR2DL4 receptors on NK cells; ${ }^{(19,20)}$

4. presentation not of peptides, but of glycolipids by CD1 (a-d) molecules (belonging to the HLA family) for recognition by a subpopulation of $\gamma \delta \mathrm{T}$ cells, ${ }^{(21,22)}$

5. exchange of proteasome components, in the presence of interferon- $\gamma$ secreted by activated $\mathrm{T}$ cells. Components of the 20S subunit are substituted to constitute a transient immunoproteasome, capable of producing more immunogenic peptides; ${ }^{(23,24)}$

6. neo-peptide formation by the ligation of two smaller fragments during their passage through the proteasome. These peptides are immunogenic and considered to be an additional mechanism for tumor cell recognition by cytotoxic T lymphocytes; ${ }^{(2)}$

7. alternative peptide formation by unconventional proteases like thimet oligopeptidase or angiotensinconverting enzyme; ${ }^{(25,26)}$

8. changes in the peptidome due to modified messenger RNA transcription patterns operated by micro-RNAs ${ }^{(27)}$ or to immunogenic peptides produced from deliberately truncated messenger RNA; (28)

9. peptide transfer between cells through the gap junctions; ${ }^{(29)}$ 
10. cross-presentation of peptides from exogenous sources $^{(30)}$ or transported into the cell by Hsp70. ${ }^{(31)}$

\section{Peptide presentation via HLAll}

In spite of the great structural similarity and shared function of antigen presentation, HLAI and HLAII exhibit important differences in expression profile and source of peptides loaded, leading to a very different role in the adaptive immune response.

In HLAII molecules, the groove will also be usually filled with a peptide, but now resulting from processing of exogenous antigens transferred into the cell (internalized) in specialized antigen processing cells (APC). B lymphocytes internalize proteins in a unique way, capturing them by binding to cell surface immunoglobulin, namely, the $\mathrm{B}$ cell receptors. ${ }^{(32)}$ Dendritic cells and macrophages are capable of internalizing not only extracellular pathogens but also particulate matter, resulting from cellular necrosis, immune complexes, complement-opsonized cell fragments, and apoptotic bodies, all additional sources of material foreign to the organism or of self-proteins to be presented by HLAII. ${ }^{(33)}$

Novel forms of antigen capture recently identified include binding to DEC205, a receptor capable of transporting antigen directly to late endosomes in which the final assembly with HLAII is carried out; ${ }^{(34)}$ trogocytosis, in which plasma membrane fragments are exchanged between cells; ${ }^{(35)}$ intercellular transfer by exosomes, ${ }^{(36)}$ also a source of tumor antigens to be targeted by cytotoxic $\mathrm{T}$ cells, ${ }^{(37)}$ and autophagy. ${ }^{(3,38)}$ Autophagosomes as well as endocytosis of cytosolic and nuclear proteins (microautophagy) are important sources increasing the offer of proteins to be presented. ${ }^{(3)}$

Activation and ensuing maturation of the phagosome or autophagosome occurs when pathogen-associated or damage-associated molecular patterns (PAMPs and DAMPs, respectively) are recognized by specific Tolllike receptors (for example, TLR4 or TLR9) ${ }^{(39)}$ and is necessary for fusion with lysosomes. During digestion by the lysosomal enzymes fragments of different sizes, usually around 25 amino acids and therefore longer than those produced by proteasomal degradation, are generated. Trimming will reduce these peptides to 14 or 15 residues. ${ }^{(40)}$ Several factors will influence the peptides available for presentation. As expected, abundant proteins have increased chances of providing peptides. Lysosomal enzymes, like carboxypeptidase and cathepsins, cleave proteins preferably on dibasic arginine and lysine sites $^{(41)}$ and peptides presented by HLAII frequently carry a N-terminal proline due to $\mathrm{N}$-aminopeptidase activity. ${ }^{(42)}$ These peptides will be coupled to HLAII during the formation of a late endosomal compartment known as MIIC. ${ }^{(43)}$

Peptide transport is quite different from the one described for HLAI, in spite of the fact that all MHC chains are synthesized and their $\alpha \beta$ heterodimers formed in the endoplasmic reticulum. We have seen that class I molecules receive their peptides while still in the reticulum being stabilized with help from the PLC. In contrast, class II molecules must be transferred to the phagolysosome for final assembly. To acquire the necessary stability for this transfer, coupling to a third protein, the invariant gamma chain takes place. In addition to directing the HLAII to the MIIC compartment, ${ }^{(44)}$ part of the invariant chain covers the groove, blocking the access of TAP-transported peptides destined for class I presentation. ${ }^{(45)}$

Once the endosomal compartment is reached, the invariant chain is digested by catepsin $\mathrm{B},{ }^{(46)}$ leaving behind only the fragment covering the groove known as CLIP (Class II - associated Invariant chain Peptide). ${ }^{(47)}$ The substitution of any other peptide for CLIP is catalyzed by the class II heterodimer HLA-DM, ${ }^{(48,49)}$ which also acts as chaperone to class II molecules, maintaining the structure intact while the exchange takes place. ${ }^{(50)}$ In B lymphocytes, HLA-DO further influences the efficiency of HLA-DM as a peptide acceptor by inhibiting its activity in neutral $\mathrm{pH}$. Upon reaching the endolysosomal compartment in which $\mathrm{pH}$ is 4.5, HLA-DM function is restored opening way for binding of peptides from extracellular origin. ${ }^{(51)}$ The peptide exchange goes on until a high affinity peptide is bound to the groove, forming a stable complex that can be transported to the cell surface of the APC. The complex process of transporting the HLAII/peptide trimmer will need further assistance from tetraspanin family proteins CD63 and CD81(52) that assist in moving through the multilamellar and multivesicular MIIC endosomes. ${ }^{(52,53)}$

\section{ANTIGEN PRESENTATION: DIVERSITY AND EFFICIENCY OF THE TRIMOLECULAR COMPLEX}

The concept of antigen presentation was initially outlined based on a series of studies carried out in the 1970 that opened way for the pioneering work done by Zinkernagel and Doherty ${ }^{(54)}$ for which they received the 1996 Nobel Prize. Today, we know that T lymphocytes are capable of recognizing antigens solely when present 
on the cell surface. These originate from all types of sources such as intracellular bacteria and viruses, byproducts of cell metabolism, self and foreign proteins and lipids. All these antigens are captured, processed, and presented in the form of mainly peptide fragments by the HLA family of glycoproteins.

Overall, antigen presentation can explain different events such as thymic education, response against infection, transplant rejection, autoimmunity, and tumor immunity. It is therefore a highly relevant topic in immunology and still of great interest in research.

Recent studies have also clarified the role of peptide production and presentation on the quality of $\mathrm{T}$ lymphocyte responses. ${ }^{(55)}$ According to the type of cell in charge of presenting antigen, the number of a specific peptide presented on each cell, the quantity and type of co-stimulatory molecules, the type and condition of the tissue where this cell located, the complexity and variety of the peptides presented, and the $\mathrm{T}$ cell receptor binding affinity for that particular peptide/HLA complex, the response elicited may result in different cytokine production profiles and specific response patterns by individual cells or subpopulations. Furthermore, these response patterns are influenced by the genetic background of each person.

Of note, when compared to the smaller closed groove of the HLAI the open HLAII groove is more permissive to peptide substitutions even when the molecule is already stable and anchored on the cell surface. In fact, as the usual peptides are longer than the class II groove, which accepts 9 amino acids in an extended conformation, flanking amino acids will be freely exposed on the surface. ${ }^{(56)}$ It becomes thus understandable that recognition by the $\mathrm{T}$ cell receptor on the surface of the CD4+ T cells is very plastic and includes not only the borders of the HLA molecule but also regions of the peptides both inside and outside the groove.

In summary, phagocytic cells respond differentially to their internalized content, inducing inflammatory or suppressive responses locally. The central role in orchestrating humoral and cellular immune responses confers a unique importance to the HLAII/peptide complex to be recognized by the CD4+ T cells. Antigen recognition leads to activation, clonal expansion, and differentiation of lymphocytes involved in the process, increasing the population of effector lymphocytes and spurring maintenance of some long-lived cells that will form the immunological memory.
The sum of the gene polymorphism present in the molecules involved in adaptive immune responses and the diversity in the processing and peptide presentation, allied to the mechanisms of gene rearrangement that produce the highly diversified $\mathrm{T}$ cell repertoire translates into a unique and highly efficient system of antigen recognition and effective immune response.

Note: Due to publishing constraints innumerable references have not been included in this review of a topic under close examination for the past 40 years. We hope all researchers with significant contributions to the subject have been cited at some point of the text.

\section{REFERENCES}

1. Bjorkman PJ, Saper MA, Samraoui B, Bennett WS, Strominger JL, Wiley DC. Structure of the human class I histocompatibility antigen, HLA-A2. Nature. 1987;329(6139):506-12.

2. Neefjes J, Jongsma ML, Paul P, Bakke 0. Towards a systems understanding of MHC class I and MHC class II antigen presentation. Nat Rev Immunol. 2011:11(12):823-36. Review.

3. Vyas JM, Van der Veen AG, Ploegh HL. The known unknowns of antigen processing and presentation. Nat Rev Immunol. 2008;8(8):607-18. Review.

4. Mester G, Hoffmann V, Stevanović S. Insights into MHC class I antigen processing gained from large-scale analysis of class I ligands. Cell Mol Life Sci. 2011;68(9):1521-32. Review.

5. Vigneron N, Van den Eynde BJ. Proteasome subtypes and the processing of tumor antigens: increasing antigenic diversity. Curr Opin Immunol. 2012; 24(1):84-91. Review.

6. Dolan BP, Sharma AA, Gibbs JS, Cunningham TJ, Bennink JR, Yewdell JW. $\mathrm{MHC}$ class I antigen processing distinguishes endogenous antigens based on their translation from cellular vs. viral mRNA. Proc Natl Acad Sci U S A. 2012;109(18):7025-30

7. Kuznetsov G, Nigam SK. Folding of secretory and membrane proteins. N Engl J Med. 1998;339(23):1688-95. Review.

8. Steimle V, Siegrist CA, Mottet A, Lisowska-Grospierre B, Mach B. Regulation of $\mathrm{MHC}$ class II expression by interferon-gamma mediated by the transactivator gene CIITA. Science. 1994;265(5168):106-9.

9. Li M, Wang IX, Li Y, Bruzel A, Richards AL, Toung JM, et al. Widespread RNA and DNA sequence differences in the human transcriptome. Science. 2011;333(6038):53-8.

10. Rock KL, York IA, Saric T, Goldberg AL. Protein degradation and the generation of MHC class I-presented peptides. Adv Immunol. 2002;80:1-70. Review.

11. Wearsch PA, Cresswell P. The quality control of MHC class I peptide loading Curr Opin Cell Biol. 2008;20(6):624-31. Review.

12. Basu S, Srivastava PK. Calreticulin, a peptide-binding chaperone of the endoplasmic reticulum, elicits tumor- and peptide-specific immunity. J Exp Med. 1999;189(5):797-802.

13. Spee P, Neefjes J. TAP-translocated peptides specifically bind proteins in the endoplasmic reticulum, including gp96, protein disulfide isomerase and calreticulin. Eur J Immunol. 1997;27(9):2441-9.

14. Saric T, Chang SC, Hattori A, York IA, Markant S, Rock KL, et al. An IFN-gammainduced aminopeptidase in the ER, ERAP1, trims precursors to MHC class I-presented peptides. Nat Immunol. 2002;3(12):1169-76. 
15. Schubert U, Antón LC, Gibbs J, Norbury CC, Yewdell JW, Bennink JR. Rapid degradation of a large fraction of newly synthesized proteins by proteasomes. Nature. 2000;404(6779):770-4.

16. Røder G, Geironson L, Bressendorff I, Paulsson K. Viral proteins interfering with antigen presentation target the major histocompatibility complex class I peptide-loading complex. J Virol. 2008;82(17):8246-52. Review.

17. Neefjes JJ, Ploegh HL. Allele and locus-specific differences in cell surface expression and the association of HLA class I heavy chain with beta 2-microglobulin: differential effects of inhibition of glycosylation on class I subunit association. Eur J Immunol. 1988;18(5):801-10.

18. Brooks AG, Borrego F, Posch PE, Patamawenu A, Scorzelli CJ, Ulbrecht M, et al. Specific recognition of HLA-E, but not classical, HLA class I molecules by soluble CD94/NKG2A and NK cells. J Immunol. 1999;162(1):305-13.

19. Pazmany L, Mandelboim O, Valés-Gómez M, Davis DM, Reyburn HT, Strominger JL. Protection from natural killer cell-mediated lysis by HLA-G expression on target cells. Science. 1996;274(5288):792-5.

20. Rajagopalan S, Long EO. A human histocompatibility leukocyte antigen (HLA)-G-specific receptor expressed on all natural killer cells. J Exp Med. 1999;189(7):1093-100. Erratum in: J Exp Med. 2000;191(11): following 2027.

21. Schofield L, McConville MJ, Hansen D, Campbell AS, Fraser-Reid B, Grusby MJ, et al. CD1d-restricted immunoglobulin G formation to GPI-anchored antigens mediated by NKT cells. Science. 1999;283(5399):225-9

22. Zeng Z, Castaño AR, Segelke BW, Stura EA, Peterson PA, Wilson IA. Crystal structure of mouse CD1: An MHC-like fold with a large hydrophobic binding groove. Science. 1997;277(5324):339-45.

23. Tanaka K. Role of proteasomes modified by interferon-gamma in antigen processing. J Leukoc Biol. 1994;56(5):571-5. Review.

24. Heink S, Ludwig D, Kloetzel PM, Krüger E. IFN-gamma-induced immune adaptation of the proteasome system is an accelerated and transient response. Proc Natl Acad Sci U S A. 2005;102(26):9241-6.

25. York IA, Mo AX, Lemerise K, Zeng W, Shen Y, Abraham CR, et al. The cytosolic endopeptidase, thimet oligopeptidase, destroys antigenic peptides and limits the extent of MHC class I antigen presentation. Immunity. 2003;18(3):429-40.

26. Shen $X Z$, Lukacher AE, Billet S, Williams IR, Bernstein KE. Expression of angiotensin-converting enzyme changes major histocompatibility complex class I peptide presentation by modifying $\mathrm{C}$ termini of peptide precursors. J Biol Chem. 2008;283(15):9957-65.

27. Gu W, Cochrane M, Leggatt GR, Payne E, Choyce A, Zhou F, et al. Both treated and untreated tumors are eliminated by short hairpin RNA-based induction of target-specific immune responses. Proc Natl Acad Sci U S A. 2009;106(20):8314-9.

28. Apcher S, Daskalogianni C, Lejeune F, Manoury B, Imhoos G, Heslop L, et al. Major source of antigenic peptides for the MHC class I pathway is produced during the pioneer round of mRNA translation. Proc Natl Acad Sci U S A. 2011;108(28):11572-7.

29. Neijssen J, Herberts C, Drijfhout JW, Reits E, Janssen L, Neefjes J. Crosspresentation by intercellular peptide transfer through gap junctions. Nature. 2005;434(7029):83-8.

30. Kurts C, Robinson BW, Knolle PA. Cross-priming in health and disease. Nat Rev Immunol. 2010;10(6):403-14. Review.

31. Castellino F, Boucher PE, Eichelberg K, Mayhew M, Rothman JE, Houghton AN, et al. Receptor-mediated uptake of antigen/heat shock protein complexes results in major histocompatibility complex class I antigen presentation via two distinct processing pathways. J Exp Med. 2000;191(11):1957-64.

32. West MA, Lucocq JM, Watts C. Antigen processing and class II MHC peptide-loading compartments in human B-lymphoblastoid cells. Nature. 1994;369(6476):147-51.
33. Villadangos JA, Young L. Antigen-presentation properties of plasmacytoid dendritic cells. Immunity. 2008;29(3):352-61. Review.

34. Mahnke K, Guo M, Lee S, Sepulveda H, Swain SL, Nussenzweig M, et al. The dendritic cell receptor for endocytosis, DEC-205, can recycle and enhance antigen presentation via major histocompatibility complex class II-positive lysosomal compartments. J Cell Biol. 2000;151(3):673-84.

35. Wakim LM, Bevan MJ. Cross-dressed dendritic cells drive memory CD8+ T-cell activation after viral infection. Nature. 2011;471(7340):629-32.

36. Théry C, Boussac M, Véron P, Ricciardi-Castagnoli P, Raposo G, Garin J, et al. Proteomic analysis of dendritic cell-derived exosomes: a secreted subcellular compartment distinct from apoptotic vesicles. J Immunol. 2001; 166(12):7309-18.

37. Wolfers J, Lozier A, Raposo G, Regnault A, Théry C, Masurier C, et al. Tumorderived exosomes are a source of shared tumor rejection antigens for CTL cross-priming. Nat Med. 2001;7(3):297-303.

38. Lerena C, Calligaris SD, Colombo MI. Autophagy: for better or for worse, in good times or in bad times. Curr Mol Med. 2008;8(2):92-101. Review.

39. Seong SY, Matzinger P. Hydrophobicity: an ancient damage-associated molecular pattern that initiates innate immune responses. Nat Rev Immunol. 2004;4(6):469-78.

40. Vogt $A B$, Kropshofer $H$, Moldenhauer G, Hämmerling GJ. Kinetic analysis of peptide loading onto HLA-DR molecules mediated by HLA-DM. Proc Nat Acad Sci U S A. 1996;93(18):9724-9.

41. Moudgil KD, Sekiguchi D, Kim SY, Sercarz EE. Immunodominance is independent of structural constraints: each region within hen eggwhite lysozyme is potentially available upon processing of native antigen. J Immunol. 1997; 159(6):2574-9.

42. Falk K, Rötzschke O, Stevanović S, Jung G, Rammensee HG. Pool sequencing of natural HLA-DR, D0, and DP ligands reveals detailed peptide motifs, constraints of processing, and general rules. Immunogenetics. 1994;39(4): 230-42.

43. Harding CV, Geuze HJ. Immunogenic peptides bind to class II MHC molecules in an early lysosomal compartment. J Immunol. 1993;151(8):3988-98.

44. Landsverk OJ, Bakke 0, Gregers TF. MHC II and the endocytic pathway: regulation by invariant chain. Scand J Immunol. 2009;70(3):184-93. Review.

45. Stumptner P, Benaroch P. Interaction of MHC class II molecules with the invariant chain: role of the invariant chain (81-90) region. EMBO J. 1997; 16(19):5807-18.

46. Roche PA, Cresswell P. Proteolysis of the class II-associated invariant chain generates a peptide binding site in intracellular HLA-DR molecules. Proc Natl Acad Sci US A. 1991;88(8):3150-4.

47. Newcomb JR, Cresswell P. Structural analysis of proteolytic products of MHC class II-invariant chain complexes generated in vivo. J Immunol. 1993;151(8):4153-63.

48. Kropshofer H, Vogt AB, Moldenhauer G, Hammer J, Blum JS, Hämmerling GJ. Editing of the HLA-DR-peptide repertoire by HLA-DM. EMBO J. 1996; 15(22):6144-54.

49. Denzin LK, Cresswell P. HLA-DM induces CLIP dissociation from MHC class II alpha beta dimers and facilitates peptide loading. Cell. 1995;82(1):155-65.

50. Mosyak L, Zaller DM, Wiley DC. The structure of HLA-DM, the peptide exchange catalyst that loads antigen onto class $\| \mathrm{MHC}$ molecules during antigen presentation. Immunity. 1998;9(3):377-83.

51. Liljedahl M, Winqvist 0 , Surh CD, Wong P, Ngo K, Teyton L, et al. Altered antigen presentation in mice lacking H2-0. Immunity. 1998;8(2):233-43.

52. Hoorn T, Paul P, Janssen L, Janssen H, Neefjes J. Dynamics within tetraspanin pairs affect MHC class II expression. J Cell Sci. 2012;125(Pt 2):328-39.

53. Zwart W, Griekspoor A, Kuijl C, Marsman M, van Rheenen J, Janssen H, 
et al. Spatial separation of HLA-DM/HLA-DR interactions within MIIC and phagosome-induced immune escape. Immunity. 2005;22(2):221-33.

54. Zinkernagel RM, Doherty PC. Restriction of in vitro T cell-mediated cytotoxicity in lymphocytic choriomeningitis within a syngeneic or semiallogeneic system. Nature. 1974;248(5450):701-2.
55. Murray JS. How the MHC selects Th1/Th2 immunity. Immunol Today. 1998; 19(4):157-63. Review.

56. Carson RT, Vignali KM, Woodland DL, Vignali DA. T cell receptor recognition of MHC class II-bound peptide flanking residues enhances immunogenicity and results in altered TCR V region usage. Immunity. 1997;7(3):387-99. 